\title{
Hepatitis C Coinfection Among People Living with HIV in a University Hospital in İstanbul
}

\section{İstanbul'da Bir Üniversite Hastanesinde HIV ile Yașayan Bireylerde Hepatit C Koenfeksiyonu}

\author{
(1) Pınar Ergen, (1) Hülya Çaşkurlu \\ Istanbul Medeniyet University, Göztepe Training and Research Hospital, Clinic of Infectious Diseases and Clinical Microbiology, Istanbul, Turkey
}

\begin{abstract}
Objectives: Human immunodeficiency virus (HIV) has infected millions of people throughout the world and may co-exist with other infections due to common ways of transmission. In our study, we aim to assess the prevalence of hepatitis $\mathrm{C}$ virus (HCV) coinfection among people living with HIV (PLWH) as well as infection transmission ways, treatment responses of the treated patients. Materials and Methods: Five hundred thirty PLWH were included in the study, monitored in our clinic between 2014 and 2020. Age, gender, education level, date of diagnosis and follow-up period, transmission ways, clinical observations and anti-HCV data of patients were retrospectively analyzed.

Results: Of the subjects $92.3 \%(n=489)$ were males, and $7.7 \%$ $(n=41)$ were females. $1.7 \%(n=9)$ of patients were detected with anti-HCV positivity. $0.6 \%(n=3)$ of the anti-HIV positive patients had active hepatitis $\mathrm{C}$ infection. Anti-HCV positivity was found to be 65 times higher in injecting drug users.

Conclusion: There is no vaccine or post-exposure prophylaxis to protect against HCV. Therefore, HCV has to be monitored in followup visits for PLWH, risk factors should be identified, and the patients should be raised awareness of transmission and protection ways. Immediately started antiviral treatment when diagnosed with $\mathrm{HCV}$. Antiviral therapy should be immediately started when HCV is diagnosed.
\end{abstract}

Keywords: HCV, HIV, coinfection

\section{$0 ̈ Z$}

Amaç: Dünyada milyonlarca insanı etkileyen insan bağışıklık yetmezlik virüsü (HIV), ortak bulaş yolları nedeniyle başka enfeksiyon etkenleri ile birlikte olabilir. Çalışmamızda HIV ile yaşayan bireylerde hepatit C virüs (HCV) koenfeksiyon sıklığını, bulaş yollarını ve tedavi almış hastalarda tedavi cevabını değerlendirmeyi amaçladık.

Gereç ve Yöntemler: 2014-2020 yılları arasında kliniğimizde takip edilen 530 HIV ile yaşayan birey çalışmaya alındı. Hastalara ait yaş, cinsiyet, eğitim düzeyi, tanı tarihi ve takip süresi, bulaşma yolları, klinik izlemleri ile anti-HCV verileri retrospektif olarak incelendi. Bulgular: Olguların \%92,3 ( $n=489)$ erkek, \%7,7 ( $n=41)$ kadın idi. Hastaların \%1,7'sinde ( $n=9)$ anti-HCV pozitifliği saptandı. Anti-HCV pozitif hastaların \%0,6'sında ( $n=3)$ aktif hepatit $C$ enfeksiyonu mevcuttu. Damar içi madde kullananlarda anti HCV pozitifliği 65 kat daha yüksek bulundu.

Sonuç: HCV'ye karşı koruma sağlayacak bir aşı veya temas sonrası profilaksi yoktur. Bu nedenle, HIV ile enfekte bireylerin takiplerinde HCV izlenmeli, risk faktörleri belirlenmeli, hastalar bulaş ve korunma yolları konusunda bilinçlendirilmelidir. HCV teşhisi konduğunda hemen antiviral tedaviye başlanmalıdır.

Anahtar Kelimeler: HCV, HIV, koenfeksiyon

Ergen P, Çaşkurlu H. Hepatitis C Coinfection Among People Living with HIV in a University Hospital in İstanbul. Viral Hepat J. 2021;27:57-62. 


\section{Introduction}

In Turkey, there are 25,809 people living with HIV (PLWH) verified as of November 2020 (1). These people face several coinfections due to common transmission ways, including viral hepatitis $B$ and C. Hepatitis $C$ virus $(\mathrm{HCV})$ main difference from hepatitis $B$ is that it has no vaccine or post-exposure prophylaxis. In particular the individuals who have shared a contaminated needle and injection, and who made unprotected sexual intercourse are invariably at risk. With highly active antiretroviral therapy (HAART), human immunodeficiency virus (HIV)-based opportunistic enfections opportunistic infections were decreased, and life expectancy prolongation and higher quality of life were increased, whereas morbities and mortalities second to such infections-secondary to such infections as viral hepatitis C have remained critical (2). Several studies have reported that progression of liver disease is three times more likely in people with HIV/HCV coenfectioncoinfection (3).

In our study, we aim to assess hepatitis $C$ prevelance among PLWH we have followed up in our clinic, transmission ways and treatment responses of the treated patients.

\section{Materials and Methods}

Five hundred thirty PLWH were included in the study, followed up in Infectious Diseases and Clinical Microbiology at Istanbul Medeniyet University, Göztepe Training and Research Hospital, from January 2014 to September 2020. The data from patient files and electronic records were retrospectively reviewed, including the demographic information, HCV prevelances, transmission ways, treatment information, treatment results and clinical observations of the patients. ELISA was used for anti HCV serology, and polymerase chain reaction for HIV RNA.

Our study was approved by the Ethics Committee of Istanbul Medeniyet University, Göztepe Training and Research Hospital (approval number: 2020/0457). All participants were informed about the study before it was conducted and their verbal consents were obtained.

\section{Statistical Analysis}

Number Cruncher Statistical System (Kaysville, Utah, USA) was used for statistical analyses. The datas were-the data were reviewed using descriptive statistical methods (mean, standard deviation, median, frequency, ratio, minimum and maximum). Kolmogorov-Smirnov and Shapiro-Wilk tested normal distribution of quantitative data as well as graphical evaluations. For paired comparisons of the normally distributed quantitative data Student's t-test was used, and Mann-Whitney $U$ test for paired comparisons of the non-normally distributed data was used. Pearson chi-square test, Fisher-Freeman-Halton exact test and Fisher's exact test were used for qualitative data. Significance level was defined as $p<0.05$.

\section{Results}

Between January 2014 and September 2020, 530 PLWH was studied; $92.3 \%(n=489)$ were males, and $7.7 \%(n=41)$ females. The median age of the patients was 37 (18 to 88 ), and the median length of follow-up was 4 years (0 to 6). $67.5 \%(n=330)$ of the patients were men who had sex with other men (MSM). The most prevalent way of HIV infection transmission was sexual intercourse; $62.3 \%$ ( $n=330)$ was homosexual, $31.7 \%(n=168)$ was heterosexual. Injecting drug use was detected for $1.3 \%(n=7)$. The distribution of descriptive characteristics of HIV-infected patients is shown in Table 1.

Anti-HCV positive was found in $1.7 \%(n=9)$ of the patients. The median age of the cases was 36 years (29 to 68), and the median length of follow-up was 4 years (0 to 5). Of these cases, $44.4 \%$ $(n=4)$ were female, $55.6 \%(n=5)$ males. Injecting drug user (IDU) was at $33.3 \%(n=3)$.

Anti-HCV positive rates had no statistically significant difference depending on anti-HCV positivity rate was not statistically different according to mean ages, age groups, date of diagnosis, education level, length of follow-up, transmision way, being MSM, and CD4 T-lymphocyte count ( $p>0.05)$.

A statistically significant difference was found in anti $\mathrm{HCV}$ positive rates by gender $(p=0.003 ; p<0.01)$. HCV positivity was found to be significantly higher in women. Anti-HCV was positive in four female patients. One of these patients had a history of operation and multiple blood transfusions, one had a history of injecting drug use.

For IDU, there were statistically significant difference in antiHCV positive rates $(p=0.001 ; p<0.01)$; IDU had significantly higher anti-HCV positive rate. The ODDS rate was found to be 64.62 (95\% confidence interval: 11.81-353.6).

In Table 2, data of HIV patients were compared to those of HIV/ HCV coinfected patients. In Table 2, data of HIV infected patients with and without HCV coinfection were compared. Of anti-HIV positive patients, $0.6 \%(n=3)$ had HCV-RNA positive. All of HCVRNA positive patients were examined and all of them were genotip 3. Two of the patients were males and both were MSM and IDU. One of these patients was a Turkish citizen living abroad, who was found to have acute HCV infection and comorbid HIV infection. One patient was a female patient of foreign nationality and had a history of operation and multiple blood transfusions.

A patient used pegylated interferon alpha (Peg-IFN) plus ribavirin, and sustained one patient used Peg-IFN plus ribavirin, and had sustained virological response (SVR). Since the foreign patient did not have social security, she could not receive HCV treatment. Each patients continued to regularly use HAART. Cirrhosis and hepatocellular carcinoma were not observed in the patients during follow-up.

\section{Discussion}

The 2017 global hepatitis report of World Health Organization estimated that out of 71 million acute hepatitis $\mathrm{C}$ infected people throughout the world, 2.3 million were also HIV-coinfected (4).

Infection of HCV infection, like HIV, occurs vertically from the mother to the fetus and due to blood and blood components, sexual intercourse and injecting drug use. HIV HCV coinfection rates vary by country. It has been reported the coinfection rates were $12.16 \%$ in China (5), $25.6 \%$ in Bulgaria (6), $1 \%$ in Chile (7), $16.1 \%$ in the U.S. (8), and $13.8 \%$ in Greece (9), varying by geographical region, age group, risk group, and infection way. In addition, different studies from one country have showed that there were very significant differences depending on risk group. In Brasil, for example, a literature review reported that the rate was 


\begin{tabular}{|c|c|c|c|c|}
\hline & & $n$ & $\%$ & \\
\hline \multirow{4}{*}{ Age (years) } & Min-max (median) & - & - & $18-88(37)$ \\
\hline & $<35$ years & 216 & 40.8 & - \\
\hline & $35-44$ years & 174 & 32.8 & - \\
\hline & $\geq 65$ years & 26 & 4.9 & - \\
\hline \multirow{2}{*}{ Gender } & Males & 489 & 92.3 & - \\
\hline & Females & 41 & 7.7 & - \\
\hline Length of follow-up (years) & Min-max (median) & - & - & $0-6(4)$ \\
\hline \multirow{2}{*}{ Education level } & College & 170 & 32.1 & - \\
\hline & Unknown & 294 & 55.5 & - \\
\hline \multirow{3}{*}{ MSM (n=489 men) } & MSM (-) & 127 & 26.0 & - \\
\hline & $\operatorname{MSM}(+)$ & 330 & 67.5 & - \\
\hline & Unknown & 32 & 6.5 & - \\
\hline \multirow{3}{*}{ Transmission way } & Heterosexual intercourse & 168 & 31.7 & - \\
\hline & Homosexual intercourse & 330 & 62.3 & - \\
\hline & Unknown & 32 & 6.0 & - \\
\hline Injecting drug use & None & 523 & 98.7 & - \\
\hline Anti-HCV & Positive & 9 & 1.7 & - \\
\hline \multirow{2}{*}{ HCV-RNA $(n=9)$} & Negative & 6 & 66.7 & - \\
\hline & Positive & 3 & 33.3 & - \\
\hline
\end{tabular}

between 3.3\% and $82.4 \%$ (10). For Turkey that rate has been found to remain between $0 \%$ and $19 \%(11,12,13,14,15,16,17,18,19)$. Furthermore, the current study reports that HCV prevelance is $1.7 \%$, and active $\mathrm{HCV}$ infection $0.6 \%$, similar to many previous studies conducted in Turkey.

In literature, it has been reported that HCV infection via heterosexual intercourse was rare (20). In a study, Vandelli et al. (21) studied 895 heterosexual monogamous pairs and found that HCV infection risk via sexual intercourse was little if any. Homosexual sexual intercourse has become one of the significant risk factors $(22,23)$. The reason for the high level might be because of a false sense of security due to the HAART use and nonprotected traumatized sexual intercourse. In our study, 33.3\% (n=3) of the anti-HCV positive patients were MSM. One of these patients presented with hepatitis, nausea and vomiting and diagnosed with acute hepatitis $\mathrm{C}$ infection. The diagnosis of HIV was also made incidentally at the time of the acute HCV diagnosis.

In developed countries, injecting drug use is the key infection route of HCV (24). In a wide range of 4,306 HIV-infected patients, it has been reported that $25.1 \%$ of the patients had history of injecting drug use and were detected with HCV-positive in $78.5 \%$ of these patients. In Turkey, injecting drug use is not at the top of the list of $\mathrm{HCV}$ infection factors. It should be kept in mind that patients may make incomplete or false statements due to the fact that injecting drug use is illegal. In the current study, we showed that injecting drug use increases anti-HCV positive by 65 times. Sharing of syringes, injection applications under non-sterile conditions, unprotected sexual intercourse under the influence of 
Table 2. Comparison of HIV patients and HIV/HCV coinfected patients Comparison of HIV infected patients with and without HCV coinfection

\begin{tabular}{|c|c|c|c|c|}
\hline & & \multicolumn{2}{|l|}{ Anti-HCV } & \multirow{3}{*}{$\mathrm{p}$} \\
\hline & & Negative $(n=521)$ & Positive $(n=9)$ & \\
\hline & & n (\%) & n (\%) & \\
\hline \multirow{2}{*}{ Age (years) } & Min-max (median) & $18-881(40)$ & $29-68(36)$ & \multirow{2}{*}{${ }^{\mathrm{a}} 0.475$} \\
\hline & Mean \pm SD & $42.73 \pm 13.35$ & $45.18 \pm 12.62$ & \\
\hline \multirow{5}{*}{ Age groups } & $<35$ years & $214(41.1)$ & $2(22.2)$ & \multirow{5}{*}{${ }^{\mathrm{b}} 0.406$} \\
\hline & $35-44$ years & $170(32.6)$ & $4(44.4)$ & \\
\hline & $45-54$ years & $72(13.8)$ & $2(22.2)$ & \\
\hline & $55-64$ years & $40(7.7)$ & $0(0)$ & \\
\hline & $\geq 65$ years & $25(4.8)$ & $1(11.1)$ & \\
\hline \multirow{2}{*}{ Gender } & Males & $484(92.9)$ & $5(55.6)$ & \multirow{2}{*}{${ }^{\circ} 0.003 * *$} \\
\hline & Females & $37(7.1)$ & $4(44.4)$ & \\
\hline \multirow{2}{*}{ Length of follow-up (years) } & Min-max (median) & $0-6(4)$ & $0-5(4)$ & \multirow{2}{*}{$\mathrm{d} 0.489$} \\
\hline & Mean \pm SD & $3.69 \pm 1.83$ & $3.33 \pm 1.80$ & \\
\hline \multirow{3}{*}{ Education level ( $n=236$ ) } & Primary school & $26(11.1)$ & $1(50)$ & \multirow{3}{*}{ b 0.248} \\
\hline & High school & $39(16.7)$ & $0(0)$ & \\
\hline & College & $169(72.2)$ & $1(50)$ & \\
\hline \multirow{2}{*}{$\operatorname{MSM}(n=457)$} & MSM (-) & $125(27.7)$ & $2(40.0)$ & \multirow{2}{*}{${ }^{c} 0.621$} \\
\hline & $\operatorname{MSM}(+)$ & $327(72.3)$ & $3(60.0)$ & \\
\hline \multirow{2}{*}{ Transmission way $(n=498)$} & Heterosexual intercourse & $162(33.1)$ & $6(66.7)$ & \multirow{2}{*}{${ }^{\mathrm{e}} 0.067$} \\
\hline & Homosexual intercourse & $327(66.9)$ & $3(33.3)$ & \\
\hline \multirow{2}{*}{ Injecting drug use } & None & $517(99.2)$ & $6(66.7)$ & \multirow{2}{*}{${ }^{c} 0.001 *$} \\
\hline & IDU & $4(0.8)$ & $3(33.3)$ & \\
\hline \multirow{2}{*}{$\mathrm{CD} 4$ count cell $/ \mathrm{mm}^{3}$} & Min-max (median) & $0-4731(388)$ & $3-607(410)$ & \multirow{2}{*}{${ }^{\mathrm{d}} 0.550$} \\
\hline & Mean \pm SD & $432.16 \pm 329.04$ & $340.12 \pm 221.29$ & \\
\hline
\end{tabular}

the substance may be the reason for this. It seems that patients with a history of injecting drug use should be evaluated in terms of HIV and HCV infection.

Anti-HCV positivity was found to be significantly higher in women in our study $(n=4 / 41)$. Three patients were foreigners who were in Turkey for work. All of these patients stated that HIV transmission has happened sexually. Both HCV and HIV can be sexually transmitted. However, it should be kept in mind that some patients have a history such as surgery, multiple blood transfusions and may be transmitted by these ways.

Part of the HCV infected people spontaneously go through the disease while chronic infection develops in $75 \%$ to $85 \%$ of these patients. While some of the people infected with HCV have the disease spontaneously resolve, chronic infection develops in $75-85 \%$ of them. They could either remain asymptomatic or still have risks of cirrhosis, end-stage liver failure, and HCC progression. Studies have shown that gender, age, ethnicity, symptomatic acute infection and whether or not hepatitis B co-infection affect spontaneous HCV recovery, while HIV co-infection is one of the reasons that increase chronicity $(25,26)$.

HIV-related guidelines, national or international, recommend that anti-HCV screening should be made for all HIV-positive individuals and continued if there are ongoing risk factors such as MSM, injection drug use and when HCV positive is detected the treatment should start. In the beginning of the threapy, due to $\mathrm{HCV}$, drug interactions should be well considered in order to avoid hepatotoxic antiretroviral drug use. If viremia is detected by performing HCV RNA analysis, HCV genotype determination should be made in anti HCV positive patients. In follow-up of seronegative patients, HCV RNA should checked when unexplained elevation of liver enzyme is detected (27).

Also for the patients diagnosed with HCV infection, anti-HIV test should be required due to common transmission ways. In this study, HIV diagnosis of a patient was detected during his hospitalization due to acute hepatitis $\mathrm{C}$ infection.

Therefore, anti-HIV tests should be regularly performed for $\mathrm{HCV}$ positive patients having risky behaviors, and anti-HCV tests for HIV positive ones.

HIV/HCV coinfected people are more likely to have fibrosis, cirrhosis and related complications than only HCV positive ones, and thus early diagnosis and treatment become crucial $(26,28,29)$. In a study including 1,176 anti-HCV positive patients in America, $34 \%$ of who were coinfected, it was observed that fibrosis stages of coinfected patients were similar to those of HIV negative 
individuals 10 years older (30). In another study in which 23,441 HIV infected patient were monitored, it was found that $66.1 \%$ of 181 liver-related deaths had HCV positivity (31). In a cohort study performed in Sweden, it was showed that active HCV infection was present in $45 \%$ of deaths (32). In the present study, we observed that no patients developed cirrhosis during follow-up controls. We believe that for the HIV diagnosed patients at a young age, early detection of HCV positivity and immediate start to antiviral treatment can prevent progression of complications.

Anti-HCV positivity does not always prove the presence of active hepatitis $\mathrm{C}$ infection. Therefore, HCV-RNA should be considered, whether the individual have viremia or not. In this study, we found active infection in 3 of 9 patients were detected with anti-HCV positive. We could not start treatment two patients. We could not start treatment to two patients. A patient returnedone patient returned to his home country. One patient detected with $\mathrm{HCV}$ positivity was planned to administer direct-acting antiviral agents, however, the patient could not receive the treatment because she did not have social security. As a treatment, Peg-IFN and ribavirin was administered to one patient for 24 weeks, and HCV-RNA negativity was observed even in post-treatment followup at the $6^{\text {th }}$ month and the patients had the SVR. It was thought that the high level of SVR in our patients high level of SVR in our patient which was defined as the level of HCV-RNA that could not be measured 6 months after the end of treatment, was due to reasons such as good adherance, young age and being Caucasian.

HCV seroprevalence was not found very high in our center and it is similar to other studies conducted in our country. One of the key factors of such low prevelance was lower frequency of injection drug use. The majority of the HIV-positive population being in the young age group, as well as early diagnosis of $\mathrm{HCV}$ and HIV and early initiation of treatment prevent possible complications.

\section{Study Limitations}

The limitation of the study is that it is a retrospective study, so all patient datas all patient's data were not available

\section{Conclusion}

PLWH are at risk due to HCV without vaccine and postexposure prophilaxy. PLWH are at risk of HCV infection since there is no vaccine and postexposure prophylaxis. Patients should be made aware of transmision ways, regularly screened, and immediately started antiviral treatment when diagnosed with $\mathrm{HCV}$.

\section{Ethics}

Ethics Committee Approval: Our study was approved by the Ethics Committee of Istanbul Medeniyet University, Göztepe Training and Research Hospital (approval number: 2020/0457).

Informed Consent: All participants were informed about the study before it was conducted and their verbal consents were obtained

\section{Peer-review: Externally peer-reviewed.}

\section{Authorship Contributions}

Concept: P.E., Desing: P.E., H.Ç., Data Collection or Processing: P.E., Analysis or Interpretation: P.E., H.Ç., Literature Search: H.Ç., Writing: P.E., H.Ç.

Conflict of Interest: No conflict of interest was declared by the authors.
Financial Disclosure: The financial support of the study was provided by the researchers.

\section{References}

1. https://hsgm.saglik.gov.tr/tr/bulasici-hastaliklar/hiv-aids/hiv-aidsliste/hiv-aids-istatislik.html

2. Kang W, Tong HI, Sun Y, Lu Y. Hepatitis $\mathrm{C}$ virus infection in patients with HIV-1: epidemiology, natural history and management. Expert Rev Gastroenterol Hepatol. 2014;8:247-266.

3. Gupta P. Hepatitis C Virus and HIV Type 1 Co-Infection. Infect Dis Rep. 2013;5(Suppl 1):e7

4. WHO (2017) Global hepatitis report, 2017 https://www.who.int/ hepatitis/publications/global-hepatitis-report2017/en/

5. Shen $Y Z$, Wang ZY, Qi TK, Jiang $X Y$, Song $W$, Tang $Y$, Wang JR, Liu $L$, Zhang RF, Zheng YF, Dai ZS, Lu HZ. Serological survey of viral hepatitis markers among newly diagnosed patients with HIV/AIDS in China. HIV Med. 2013;14:167-175.

6. Alexiev I, Alexandrova M, Golkocheva-Markova E, Teoharov P, Gancheva A, Kostadinova A, Dimitrova R, Elenkov I, Chervenjakova T, Stoycheva M, Nikolova D, Varleva T, Nikolova M. High Rate of Hepatitis B and C Coinfections Among People Living with HIV-1 in Bulgaria: 2010-2014. AIDS Res Hum Retroviruses. 2017;33:228229.

7. Weitzel T, Rodríguez F, Noriega LM, Marcotti A, Duran L, Palavecino C, Porte L, Aguilera X, Wolff M, Cortes CP. Hepatitis $B$ and $C$ virus infection among HIV patients within the public and private healthcare systems in Chile: A cross-sectional serosurvey. PLoS One. 2020;15:e0227776.

8. Sherman KE, Rouster SD, Chung RT, Rajicic N. Hepatitis C Virus prevalence among patients infected with Human Immunodeficiency Virus: a cross-sectional analysis of the US adult AIDS Clinical Trials Group. Clin Infect Dis. 2002;34:831-137.

9. Dimitrakopoulos A, Takou A, Haida A, Molangeli S, Gialeraki A, Kordossis T. The prevalence of hepatitis B and C in HIV-positive Greek patients: relationship to survival of deceased AIDS patients. J Infect. 2000;40:127-131

10. Kuehlkamp VM, Schuelter-Trevisol F. Prevalence of human immunodeficiency virus/hepatitis $\mathrm{C}$ virus co-infection in Brazil and associated factors: a review. Braz J Infect Dis. 2013;17:455-463.

11. Atalay S, Tatlı Kış T, Sönmez U, Köse Ş. Hepatitis B and C Seroprevalence in Patients with Human Immunodeficiency Virus/ Acquired Immune Deficiency Syndrome at a Tertiary Care Hospital in Izmir. Viral Hepat J. 2018;24:3-6.

12. Aydin $\mathrm{OA}$, Yemisen $M$, Karaosmanoglu HK, Sargin F, Gunduz A, Ceylan B, Mete B, Ozgunes N, Sevgi DY, Ozaras R, Tabak F. Low Prevalence of Hepatitis C Virus Infection Among HIV-Positive Patients: Data From a Large-Scale Cohort Study in Istanbul, Turkey. Hepat Mon. 2014;14:e18128.

13. Kaptan F, Örmen B, Türker N, EI S, Ural S, Vardar I, Coskkun NA, Er H, Ünal Z. Insan Immün Yetmezlik Virüsü ile Enfekte 128 Olgunun Retrospektif Olarak Değerlendirilmesi. Turkiye Klinikleri J Med Sci. 2011;31:525-533

14. Inci A. HIV'le Infekte Olgularda Hepatit B ve Hepatit C Seroprevalansının Araştırılması. Klimik Derg. 2018;31:34-36.

15. Ural S, Kaptan F, Türker N, Örmen B, El S, Coskun NA, Demir C, Metin Türker M. Insan Immün Yetmezlik Virusuyla Infekte Olgularda Hepatit B Virusu ve Hepatit C Virüsü Infeksiyonu Seroprevalansı. Klimik Derg. 2010;23:100-104.

16. Şahin A, Tekin Şahin S, Namıduru M, Karaoğlan I, Boşnak V. Gaziantep Üniversitesi'ndeki HIV/AIDS Hastalarında Hepatit B ve Hepatit C Virüs Seroprevalansı Mediterr. J Infect Microb Antimicrob. 2016:5:5

17. Karaosmanoğlu HK, Aydın OA, Ince ER, Nazlıcan Ö HIVIAIDS Hastalarında Hepatit B ve Hepatit C Seroprevalansı. Viral Hepatit Dergisi. 2009;14:53-56 
18. Erbay A, Bodur H, Çolpan A, Akıncı E, Korkmaz M, Eren S. HIV/AIDS olgularının değerlendirilmesi. Türk HIV/AIDS Derg. 2003;6:43-46.

19. Sayın Kutlu S, Çelikbaş AK, Eren Ş, Kutlu M, Motor VK, Dokuzoğuz B. HIV infekte olguların hepatit B ve hepatit C ile birlikteliği. Türk HIV/ AIDS Derg. 2003;6:11-16.

20. Hull M, Shafran $S$, Wong A, Tseng A, Giguère P, Barrett L, Haider S, Conway B, Klein M, Cooper C. CIHR Canadian HIV Trials Network Coinfection and Concurrent Diseases Core Research Group: 2016 Updated Canadian HIV/Hepatitis C Adult Guidelines for Management and Treatment. Can J Infect Dis Med Microbiol. 2016;2016:4385643.

21. Vandelli C, Renzo F, Romanò L, Tisminetzky S, De Palma M, Stroffolini T, Ventura E, Zanetti A. Lack of evidence of sexual infection of hepatitis $\mathrm{C}$ among monogamous couples: results of a 10-year prospective follow-up study. Am J Gastroenterol. 2004;99:855-859

22. Urbanus AT, van de Laar TJ, Stolte IG, Schinkel J, Heijman T, Coutinho RA, Prins M. Hepatitis C virus infections among HIVinfected men who have sex with men: an expanding epidemic. AIDS. 2009;23:F1-7.

23. van de Laar T, Pybus $O$, Bruisten $S$, Brown $D$, Nelson M, Bhagani $S$, Vogel $M$, Baumgarten $A$, Chaix $M L$, Fisher $M$, Gotz $H$, Matthews GV, Neifer S, White P, Rawlinson W, Pol S, Rockstroh J, Coutinho R, Dore GJ, Dusheiko GM, Danta M. Evidence of a large, international network of HCV infection in HIV-positive men who have sex with men. Gastroenterology. 2009 ;136:1609-1617

24. Shepard CW, Finelli L, Alter MJ. Global epidemiology of hepatitis C virus infection. Lancet Infect Dis. 2005;5:558-567.
25. Hoofnagle JH. Course and outcome of hepatitis C. Hepatology. 2002;36(Suppl1):S21-29.

26. 26. Clausen LN, Lundbo LF, Benfield T. Hepatitis $C$ virus infection in the human immunodeficiency virus infected patient. World $\mathrm{J}$ Gastroenterol. 2014;20:12132-12143.

27. Sili U, Tekin A, Korten V. Chronic Viral Hepatitis in Human Immunodeficiency Virus-infected Patients. Viral Hepat J. 2016;22:39-42.

28. Blackard JT, Sherman KE. HCV/HIV co-infection: time to re-evaluate the role of HIV in the liver? J Viral Hepat. 2008;15:323-330.

29. McGovern BH. Hepatitis $\mathrm{C}$ in the HIV-infected patient. J Acquir Immune Defic Syndr. 2007;45(Suppl2):S47-56

30. Kirk GD, Mehta SH, Astemborski J, Galai N, Washington J, Higgins Y, Balagopal A, Thomas DL. HIV, age, and the severity of hepatitis $C$ virus-related liver disease: a cohort study. Ann Intern Med. 2013;158:658-666.

31. Weber R, Sabin CA, Friis-Møller N, Reiss P, El-Sadr WM, Kirk O, Dabis F, Law MG, Pradier C, De Wit S, Akerlund B, Calvo G, Monforte Ad, Rickenbach M, Ledergerber B, Phillips AN, Lundgren JD. Liver-related deaths in persons infected with the human immunodeficiency virus: the D:A:D study. Arch Intern Med. 2006;166:1632-1641.

32. Weber R, Ruppik M, Rickenbach M, Spoerri A, Furrer H, Battegay M, Cavassini M, Calmy A, Bernasconi E, Schmid P, Flepp M, Kowalska J, Ledergerber B; Swiss HIV Cohort Study (SHCS). Decreasing mortality and changing patterns of causes of death in the Swiss HIV Cohort Study. HIV Med. 2013;14:195-207. 